\title{
О горных породах, рудах и почвах в зоне влияния аэротехногенных выбросов комбината «Североникель»
}

\author{
Войтеховский Ю.Л., Нерадовский Ю.Н., Мирошниченко Т.А. \\ Геологический институт ФИЦ КНЦ РАН, Anamumbl,woyt@geoksc.apatity.ru
}

Аннотация. В статье приведены обобщенные результаты двух этапов комплексного геохимического и микробиологического исследования горных пород, руд и почв в зоне влияния аэротехногенных выбросов горно-металлургического комбината «Североникель». Исследования выполнены в рамках международного проекта КО1115 «Геобиологические угрозы в Арктическом регионе» программы приграничного сотрудничества «Коларктик».

Ключевые слова: Мончегорский рудный район, сульфидные медно-никелевые руды, кислотные дожди, бактерии, микромицеты, Коларктик, приграничное сотрудничество.

\section{On the rocks, ores and soils in the area affected by aerotechnogenic emissions of the «Severonikel» plant}

\author{
Voytekhovsky Y.L., Neradovsky Y.N., Miroshnichenko T.A. \\ Geological Institute FRC KSC RAS, Apatity,woyt@geoksc.apatity.ru
}

\begin{abstract}
The article provides consolidated results obtained during two stages of comprehensive geochemical and microbiological studies of rocks, ores and soils in the area affected by aerotechnogenic emissions of the Severonikel Dressing Plant. The research has been carried out in the framework of the international project KO1115 «Geo-Bio Hazards in the Arctic Region» under the European Neighbourhood Instrument Cross-Border Cooperation Kolarctic Programme.
\end{abstract}

Key words: Monchegorsk ore region, sulfide copper-nickel ores, acid rains, bacteria, micromycetes, Kolarctic, cross-border cooperation.

Over its 70-year long history, the Geological Institute KSC RAS has been tightly woven by professional ties with geological surveys, research and educational institutions of neighbouring Scandinavian countries. The past decade is marked with fruitful scientific collaboration in the framework of the European Neighbourhood Instrument Cross-Border Cooperation Kolarctic Programme. In 2012-2015, the Geological Institute KSC RAS cooperated with leading research institutions of Finland, Sweden and Norway in the multilateral project KO368 «ABCGHeritage - Arctic Biological, Cultural and Geological Heritage». As a result, two guidebooks on unique geological objects of the Khibiny Mountains (Voytekhovsky et al., 2014) (in Russian, Finnish and English) and adjacent areas of the Barents region (Johansson et al., 2014) (in Russian, Finnish, Norwegian and English) were published. The project was widely highlighted in mass media, at international and regional conferences.

In 2018, a new project KO1115 «Geo-Bio Hazards in the Arctic Region» was launched under the European Neighbourhood Instrument Cross-Border Cooperation Program Kolarctic 2014-2020. The project united the Geological and Mining Institutes KSC RAS, Natural Resources Institute Finland (LUKE) and Geological Surveys of Finland (Lead Partner), Sweden and Norway. The project aims at studying geobiological hazards resulted from the industrial impact on environment in cross-border Arctic areas.

The target area of the Geological Institute KSC RAS is the Monchegorsk ore region, one of the mostpolluted areas at the Kola Peninsula (fig. 1). This region-largest industrial centre was established in the 1930s to process sulfide $\mathrm{Cu}-\mathrm{Ni}$ ores of the Monchetundra. Once the ore reserves of the Nittis-KumuzhyaTravyanaya massif depleted, the plant targeted on the extraction of $\mathrm{Cu}, \mathrm{Ni}$ and PGE from feinstein provided by the «Pechenganikel» plant. Technogenic pollutions have been emitted non-stop for over 80 years. 


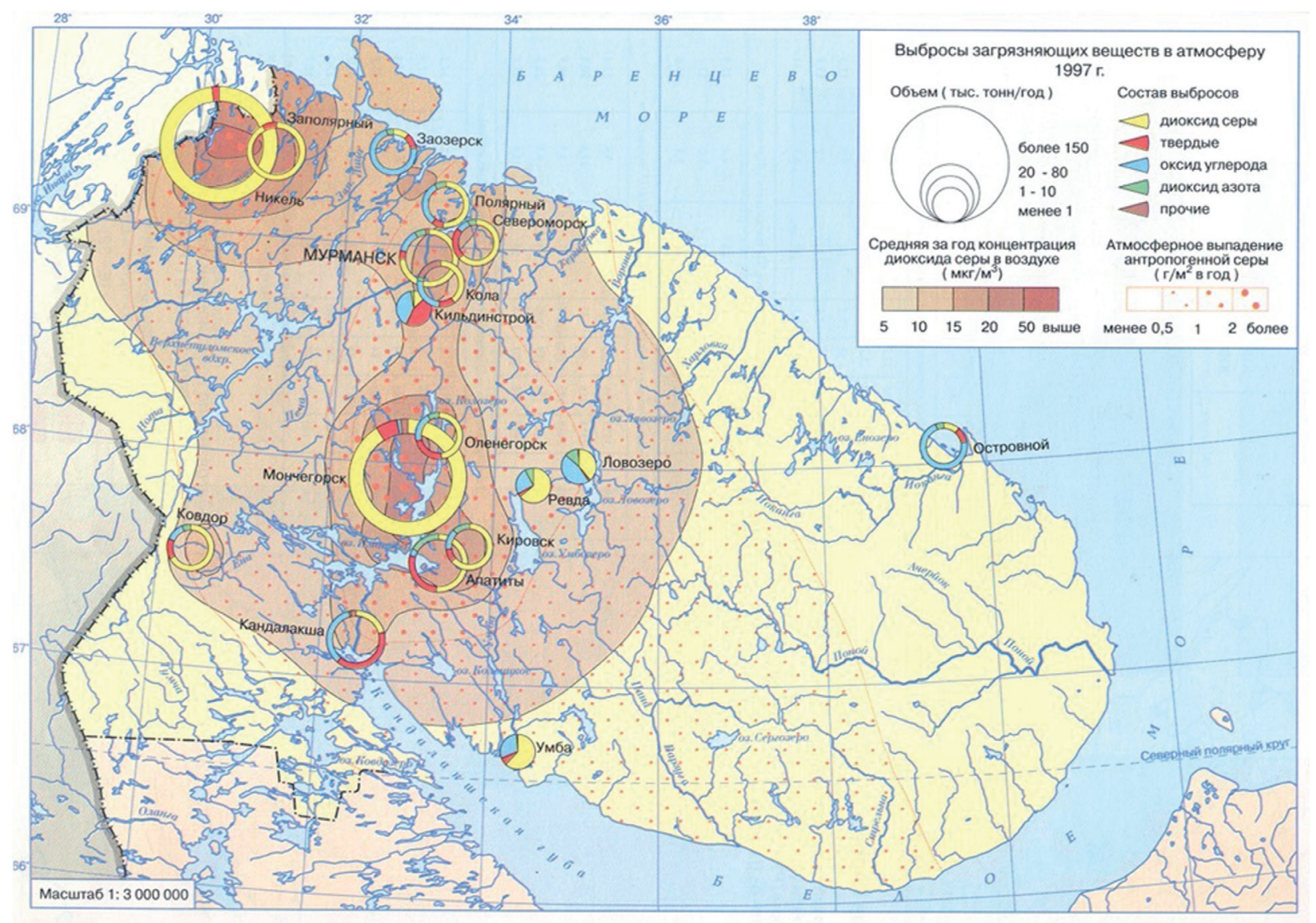

Fig. 1. Pollution of the atmospheric air in the Murmansk region (Ecological atlas..., 1999).

Рис. 1. Загрязнение атмосферного воздуха в Мурманской области (Ecological atlas..., 1999).

Pollutant concentrations in soils, lacustrine sediments and surface waters often exceed permissible limits and become geo-biological hazards (Dauvalter et al., 2009 a, b; 2010).

The impact of atmospheric acid precipitation on the landscape is so intensive, that rocks and disseminated $\mathrm{Cu}-\mathrm{Ni}$ ores of adjacent mountain massifs have been altered. Sulfide minerals are easily decomposed and produce extensive geochemical anomalies, enhancing the pollution of surface waters. Rocks decompose and become debris. In 2019, the authors provided an integrated study of alterations in rocks and ores affected by aerotechnogenic emissions of the «Severonikel» plant in the Monchegorsk area. Most changes in sulfide copper-nickel ores follow a common pattern, i.e. chalcopyrite is replaced by bornite and chrysocolla, pentlandite is replaced by violarite (along cleavage cracks) and retgersite, pyrrhotite is replaced by melnikovite-pyrite and iron hydroxides (fig. 2). The intensity of oxidation is enhanced by the fact that even stable magnetite is replaced by iron hydroxides. Readily soluble jarosite can be expected to occur in a fine mixture with them and retgersite; malachite can be expected to occur in intergrowths with chisocolla.

Lichen colonies clearly tend to occur in areas of the most intensive alterations in vein sulfide $\mathrm{Cu}-\mathrm{Ni}$ ores (Mt. Kumuzhya). Preliminary diagnostics has detected Rhizocarpon geographicum, Umbilicaria esculenta, Pertusaria, Verrucaria, Biatora, Lecanora genuses of lichen (fig. 3). The reason of their tending to the alteration areas can be permeability of crush zones for ground waters, as well as oxidation-reduction reactions, where lichens can acively participate in. The diversity of lichens near the «Severonikel» plant had not been studied earlier (Tikkanen, Niemela, 1995; Kashulina, Saltan, 2008; Urbanavichus, 2012). The obtained results, in particular, on the confinement of lichens to the areas of the most intensive oxidation of sulfide copper-nickel ores, are of high-priority.

In 2020, despite the challenging COVID-19 situation, the authors provided geochemical and microbiological studies of rocks, ores and soils in the Monchegorsk area. About 50 soil samples were collected from four sublatitudinal profiles, starting at the slopes of the Nittis-Kumuzhya-Travyanaya massif and 

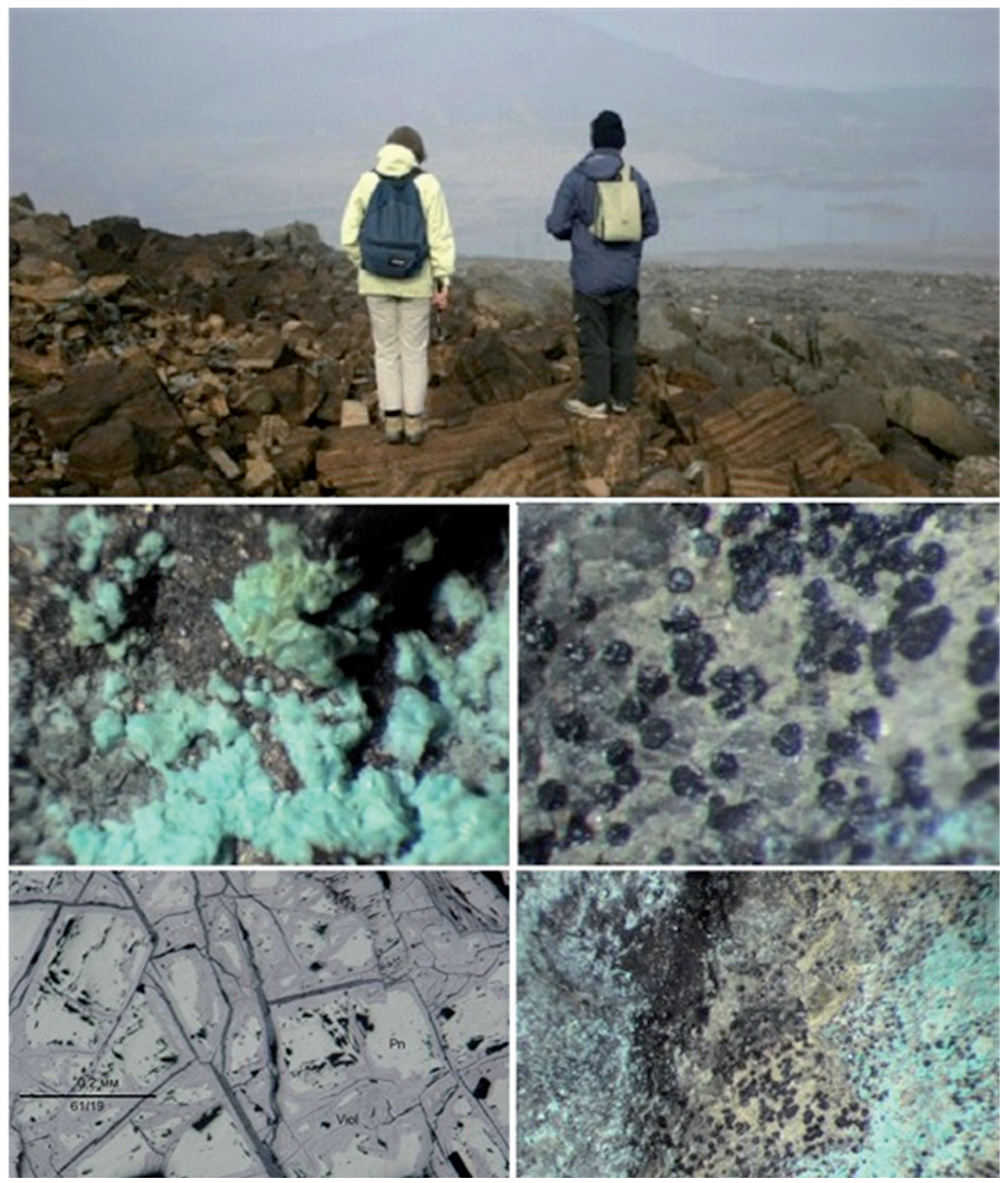

Fig. 2. Top: in the foreground - oxidized disseminated sulfide copper-nickel ores in banded olivine pyroxenites, Mt. Sopcha; in the background - smog blocking the view at the Nittis-Kumuzhya-Travyanaya massif. Middle: replacement of chalcopyrite by chrisocolla (left, green) and bornite (right, nodular-shaped black). Bottom: replacement of pentlandite of violarite (left, along cracks) and retgersite (right, green powdery coating).

Рис. 2. Вверху: на переднем плане - окисленные вкрапленные сульфидные медно-никелевые руды в расслоенных оливиновых пироксенитах, г. Сопча; на заднем плане - смог, закрывающий вид на массив Ниттис - Кумужья - Травяная. В середине: замещение халькопирита хризоколлой (слева, зеленое) и борнитом (справа, черные вкрапления). Внизу: замещение пентландита виоларитом (слева, вдоль трещин) и ретгерситом (справа, зеленые порошковатые налеты). 
spreading eastwards up to the peatland west of Monchegorsk. In situ measurements showed $\mathrm{pH}$ values to range from 3.6 to 7.2 , with $\mathrm{pH}$ increasing with the sampling depth at every point $(0.5 \mathrm{~m}, 1.0 \mathrm{~m})$.

The systematic analysis of microbiota in the soils and on the ore surface indicated a limited diversity of bacteria and micromycetes. Notably, the amount of microorganisms of various groups is considerably higher in the soils than on the ore surface, which is reasonable due to the low content or a total absence of nutrients in the latter. In the soil, the amount of bacteria is 13-650 ths cells/g, the amount of micromycetes is $0.2-12$ ths CFU/g; on the surface of the ores, the amount on cell bacteria is $35-460 \mathrm{cells} / \mathrm{cm}^{2}$, fungi buds $-2-38 \mathrm{CFU} / \mathrm{cm}^{2}$. Saprotrophic, oligotrophic, nitrifying, denitrifying and iron-oxidizing bacteria were identified in the soils and on the ore surface. Oligotrophs dominated in all samples.
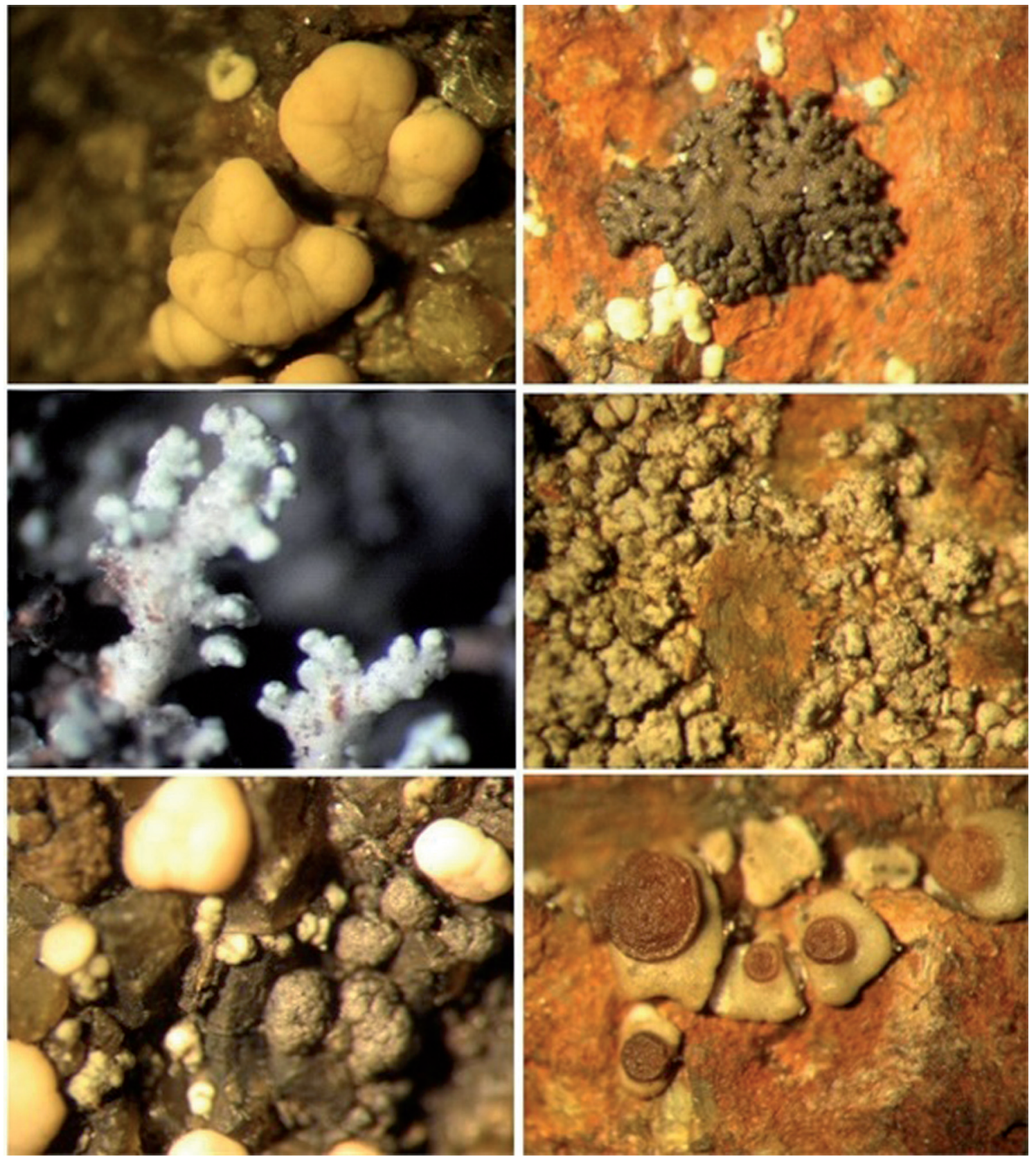

Fig. 3. Lichens actively growing on oxidized sulfide ores, Mt. Kumuzhya (from top to bottom, from left to right): Rhizocarpon geographicum, Umbilicaria esculenta, Pertusaria, Verrucaria, Biatora, Lecanora.

Рис. 3. Лишайники, активно растущие на окисленных сульфидных рудах, г. Кумужья (сверху вниз, слева направо): Rhizocarpon geographicum, Umbilicaria esculenta, Pertusaria, Verrucaria, Biatora, Lecanora. 
Micromycetes were extracted in all soil samples ( 25 species) and on the surface of the ore (10 species) (figs. 4, 5).

From 12 to 16 micromycetes were extracted in each soil sample. From 2 to 6 micromycete species were extracted from the surface of the ore samples. The similarity degree of the species composition in both cases is $47 \%$. Thus, a half of species extracted from the soil and ore surface are identical. Penicillium genus dominates in amount of species (30-50 \%) in all samples, which is typical of soils in northern regions.

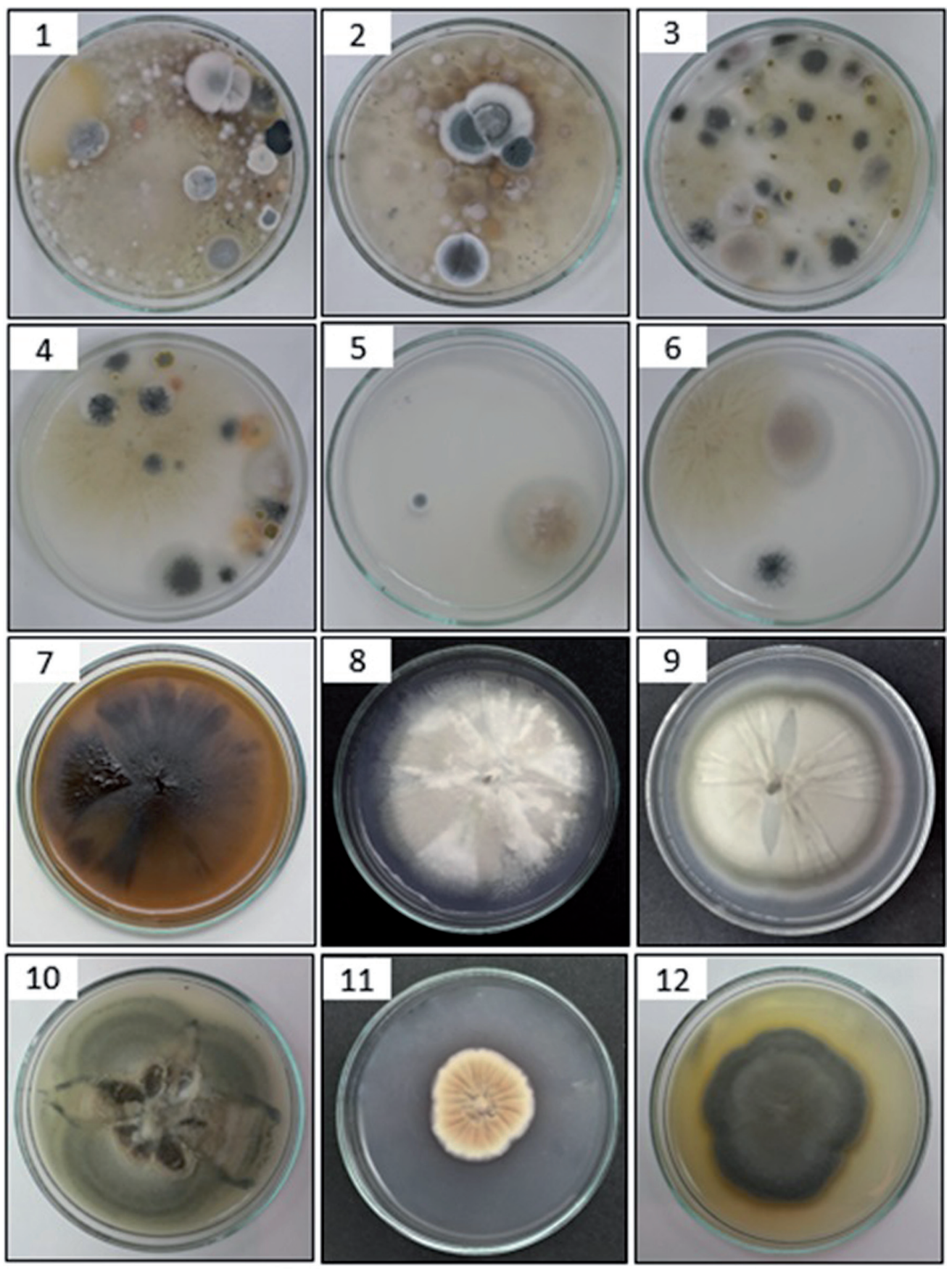

Fig. 4. Micromycetes in soils and on surface of ores: 1,2-Sabouraud medium; 3-6-Czapek-Dox medium; $7-A u$ reobasidium pullulans (de Bary \& Löwenthal) G. Arnaud; 8 - Penicillium glabrum (Wehmer) Westling; 9 - Penicillium spinulosum Thom; 10 - Penicillium herquei Bainier \& Sartory; 11 - Aspergillus versicolor (Vuill.) Tirab.; 12 - Penicillium velutinum J.F.H. Beyma.

Рис. 4. Микромицеты в почвах и на поверхности руд: 1, 2 - среда Sabouraud; 3-6 - среда Czapek-Dox; 7-12 - список видов (лат.). 


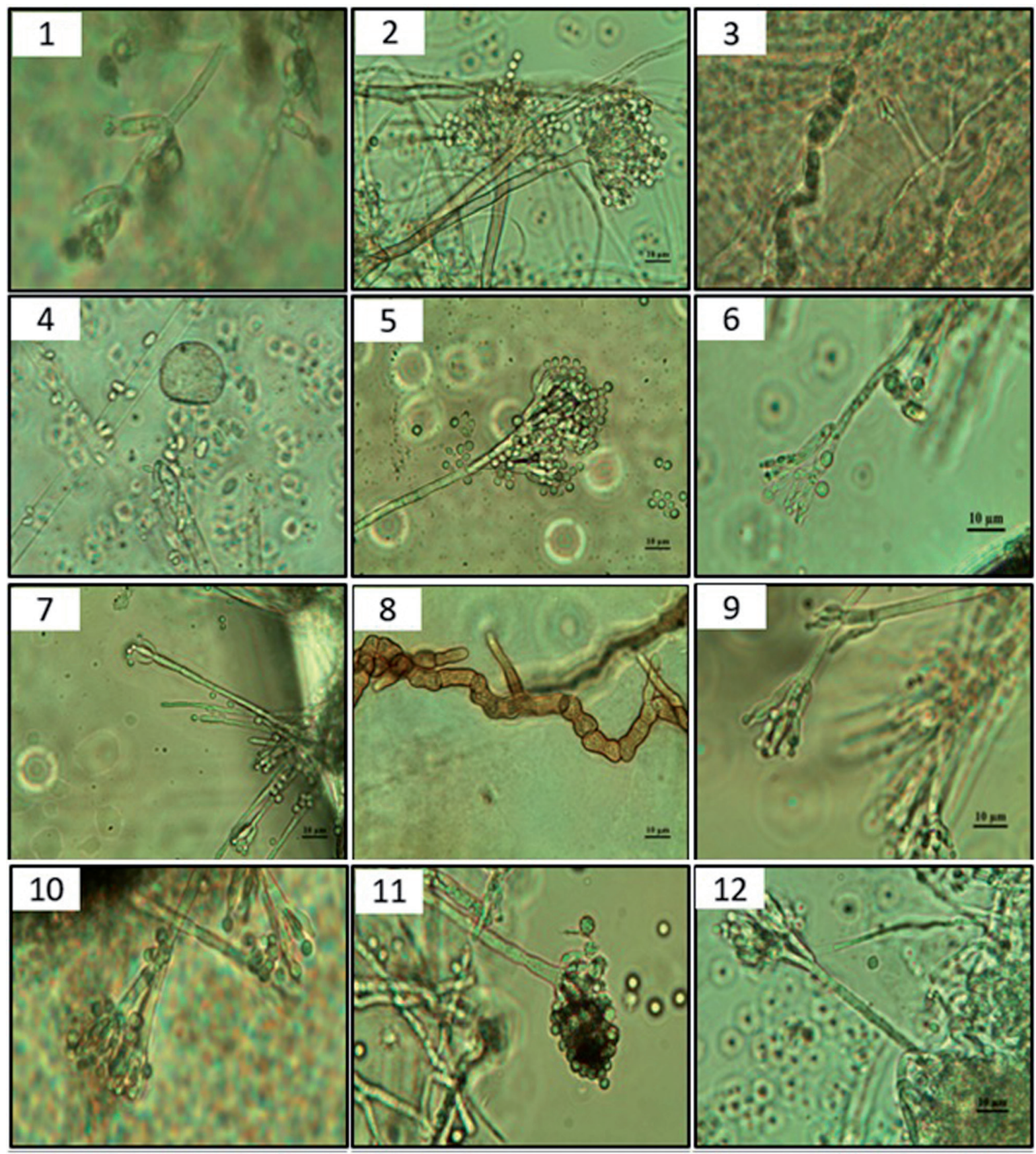

Fig. 5. Micromycetes on surface of ores: 1 - Acremonium murorum (Corda) W. Gams; 2 - Aspergillus versicolor (Vuill.) Tirab.; 3 - Gibellulopsis nigrescens (Pethybr.) Zare, W. Gams \& Summerb.; 4 - Mucor hiemalis Wehmer; 5 -Penicillium aurantiogriseum Dierckx; 6 - Penicillium canescens Sopp; 7 - Penicillium decumbens Thom; 8 -Aureobasidium pullulans (de Bary \& Löwenthal) G. Arnaud; 9 - Penicillium herquei Bainier \& Sartory; 10 - Penicillium jensenii K.W. Zaleski; 11 - Penicillium purpurescens (Sopp) Biourge; 12 - Penicillium simplicissimum (Oudem.) Thom.

Рис. 5. Микромицеты на поверхности руд. 1-12 - список видов (лат.).

Paecilomyces variotii and Acremonium murorum species were extracted from all soil samples, but these are minor. Gibellulopsis nigrescens and Sarocladium strictum species prevail in a number of samples. The micromycete structure is more even on the ore surface than in the soil, no visible dominants are observed. The highest abundance value is recorded for Penicillium spinulosum species in all samples.

Thus, it is proved that microbiota was actively involved in the geochemical transformation of rocks and ores in the area affected by aerotechnogenic emissions of the «Severonikel» plant near the Monchegorsk town in the Murmansk region. 


\section{Acknowledgements}

The project is funded by the Kolarctic CBC, EU, Russia, Norway, Sweden and Finland. This publication has been produced with the assistance of the European Union. The contents of this publication are the sole responsibility of its authors and can in no way be taken to reflect the views of the European Union. The authors are thankful to M.V. Korneykova, N.V. Fokina, E.S. Yanishevskaya and A.S. Soshina (Institute of the Industrial Ecology Problems of the North KSC RAS) for the microbiological investigations of the samples.

\section{References}

1. Dauvalter V.A., Dauvalter M.V., Saltan N.V., Semyonov E.N. The impact of the mining plant pollutants on the chemical compositions of atmospheric precipitation, Monchegorsk study area // Geoecology. Geo-Ingeneering. Hydrogeology. Geocryology. 2009 a. No. 3. P. 228-240. (in Rus.)

2. Dauvalter V.A., Dauvalter M.V., Saltan N.V., Semyonov E.N. Chemical composition of surface waters in the impact area of the «Severonikel» plant// Geochemistry. 2009 b. No. 6. P. 628-646. (in Rus.)

3. Dauvalter V.A., Dauvalter M.V., Kashulin N.A., Sandimirov S.S. The impact of the mining plant pollutants on the chemical compositions of lacustrine deposits, Monchegorsk study area // Geoecology. Geo-Ingeneering. Hydrogeology. Geocryology. 2010. No. 2. P. 129-139. (in Rus.)

4. Ecological atlas of the Murmansk region. Maps / Ed.-in-Chief G.V. Kalabin. Moscow - Murmansk - Apatity, 1999. 48 p. (in Rus.)

5. Johansson P., Lauri L.S., Voytekhovsky Y.L. Barents Tour for Geotourists. Rovaniemi: Grano Oy, 2014. 117 p.

6. Kashulina G.M., Saltan N.V. Chemical composition of plants in extreme conditions of the local area of the «Severonikel» plant. Apatity: KSC RAS, 2008. 239 p. (in Rus.)

7. Tikkanen E., Niemela I. Kola Peninsula pollutants and forest ecosystems in Lapland. Finland's Ministry of Agriculture and Forestry. The Finnish Forest Research Institute. 1995. 82 p.

8. Urbanavichus G.P. Alterating diversity of epiphytic lichens in spruce forests of the Murmansk region under the impact of aerotechnogenic emissions of the Monchegorsk copper-nickel plant // Ecological problems of North regions and ways to their solution. Proc. IV All-Russ. Sci. Conf. V. 1. Apatity: KSC RAS, 2012. P. 130-132. (in Rus.)

9. Voytekhovsky Y.L., Johansson P., Lauri L.S., Miroshnichenko T.A., Räisänen J. Khibiny Tundra. Geological Outdoor Map 1:50000 and Guidebook. Rovaniemi: Grano Oy, 2014. 56 p. 